ORIGINAL ARTICLE

* Corresponding author: Juan A. Paredes E-mail: paredes.juanandres@inta.gob.ar

\title{
Relationship between incidence and severity of peanut smut and its regional distribution in the main
} growing region of Argentina

Juan. A. Paredes*1, Juan. P. Edwards Molina ${ }^{2}$, Luis I. Cazón ${ }^{1}$, Florencia Asinari ${ }^{1}$, Joaquín H. Monguillot ${ }^{1}$, Sergio A. Morichetti ${ }^{3}$, Alejandro M. Rago ${ }^{4,5}$, Adriana M. Torres ${ }^{6}$

${ }^{1}$ Instituto de Patología Vegetal, CIAP - INTA. (X5020ICA), Córdoba, Córdoba, Argentina.

${ }^{2}$ Estación Experimental Agropecuaria - INTA. (7620), Balcarce, Buenos Aires, Argentina

${ }^{3}$ Aceitera General Deheza (AGD). (5923) General Deheza, Córdoba, Argentina

${ }^{4}$ Facultad de Agronomía y Veterinaria, UNRC. (5800), Río Cuarto, Córdoba, Argentina

${ }^{5}$ Centro de Investigaciones Agropecuarias - INTA. (X5020ICA), Córdoba, Córdoba, Argentina

${ }^{6}$ Facultad de Exactas, IMICO, UNRC. (5800), Río Cuarto, Córdoba, Argentina

\section{Abstract}

Peanut smut, caused by the soil-borne pathogen Thecaphora frezii, has increased in incidence in the main Argentinian peanut-growing regions. Smut-affected pods transforms the kernel into a mass of teliospores, which survive long-term in the soil. This study is the first large-scale (regional) survey to determine the occurrence and distribution of peanut smut in the main growing area of Argentina. Surveys were conducted in Córdoba province, in randomly selected commercial peanut fields $(\mathrm{n}=217)$ grown from 2015 to 2020 . A five-score severity scale has been used to quantify the smut severity on pods $(0=$ healthy kernels and $4=$ totally smutted kernels $)$ and a disease severity index (DSI) is calculated. Pods with severity scores of 3 and 4 are rejected by the industry and produce a high volume of spores that spread among fields increasing the inoculum in the soil. Those pods were classified as severely damaged pods (SDP). We evaluated the relative frequency of smut classes during the years and established the relationships between the yearly incidence and DSI. The mean of the incidence was variable (never zero) across the years and increased from 1.66\% in 2015 to $11.47 \%$ in 2020 . More than $80 \%$ of the affected pods belonged to SDP group. The variable SDP, a more time and cost-effective method for quantifying peanut smut, best explained the variation in DSI values. Our results suggest that that visual estimates of incidence and SDP should be useful for disease monitoring, screening genotypes, or treatments comparisons in smut management experiments. Our data update knowledge of the distribution of T. frezii in the peanut-growing area of Argentina. 
39 Peanut (Arachis hypogaea L.) is a high-value food crop cultivated worldwide. Its center of origin is the 40 northwestern Argentina and southeastern Bolivia (Hammons et al., 2016). Argentina produces high-quality 41 peanuts, mainly intended for export (approximately $90 \%$ of the production), with the European market being the principal destination. More than $90 \%$ of Argentinian peanut production is concentrated in Córdoba province in the central region of the country. Approximately 350,000 ha of peanuts are planted yearly and processed by the industry established in the same region. The major peanut-producing departments are General Roca, Rio Cuarto, and Presidente Roque Saenz Peña, located in the south of the province, with more than $65 \%$ of the total production (Agüero, 2017; Calzada \& Rozadilla, 2018).

Peanut smut, caused by Thecaphora frezii Carranza and Lindquist, is a soil-borne pathogen currently distributed throughout Córdoba province (Paredes, 2017). The first record of the disease in Argentina dates from 1995, when it was detected in Córdoba in the main peanut growing area (Marinelli et al., 1995). Since its detection, incidence has constantly increased, reaching 100\% prevalence since 2012 (Paredes, 2017; Rago et al., 2017). Infection occurs when the peg is penetrating the soil, stimulating the germination of spores located in the soil and producing local infection (Marinelli et al., 2008). Smut may completely transform the kernel into a mass of spores. Lesions of smut lead to many spores that are released at harvest when the pods are broken. $T$. frezii spores survive for a long time (several years) as teliospores in the soil (Cazón et al., 2016; Rago et al., 2017). 'Granoleico' peanut cultivar (highly susceptible) is planted in more than 70\% of cultivated areas in Argentina. Breeding programs have been screening germplasm to evaluate both tolerance and resistance of different peanut cultivars (Bennett et al., 2021; Bressano et al., 2019; Kearney et al., 2021; Wann et al., 2020). In recent years, one new cultivar with high levels of resistance to smut infection was released. However, adoption by farmers is very low due to several factors, such as seed multiplication to obtain sufficient quantities of commercial seed, low yield, and other agronomic traits.

Variability is observed in smut symptoms, from a small sorus to the complete transformation of the kernel, determining different classes of severity (Astiz Gasso et al., 2008; Rago et al., 2017). In some cases, hypertrophic

64 pods without signs of internal fungal presence have been observed (Bennett et al., 2021). Smut incidence is the 

0-4 severity class scale), where at least one or both kernels were transformed into a mass of spores, respectively

67 (Paredes et al., 2021). A disease severity index, which takes the frequency of severity classes into account, is the most common measure of intensity of smut evaluated in surveys or field experiments (Rago et al., 2017).

Peanut smut caused significant losses to peanut production in recent years in the Argentinian peanut-producing region (Paredes, 2017; Rago et al., 2017). All fields in Córdoba province present T. frezii inoculum in the soil at different concentrations (spores per gram of soil), resulting in variable disease incidence, from less than $1 \%$ to more than $50 \%$. Commercial peanut fields may be classified according to smut percent incidence: low $(<4 \%)$, medium (4 to 20\%), or high (> 20\%). Smut surveys in peanut-producing areas of Córdoba have shown a decrease in disease intensity from north to south (Paredes et al., 2016). This gradient is due to the fact that peanut processing factories are located principally in the north and are an important source of spore dispersal. During shelling, smutted kernels release teliospores that are dispersed by wind, increasing soil inoculum in nearby fields. In addition, new production areas are in the south of the Cordoba province where the history of peanut crops is shorter than in the north (Cazón et al., 2018; Paredes, 2017; Rago et al., 2017). Paredes (2017) reported peanut yield loss due to smut in the magnitude of 27,419 MT (US\$14,151,800), representing 3.15\% of total production. The highest yield losses of $35 \%$ were estimated in highly infested fields (>50\% incidence).

The quantification of severity (the degree of infection) is more laborious, but it best expresses the intensity of smut. This can be estimated visually with enhanced accuracy by means of a diagrammatic scale as an aid during the assessments (Bock et al., 2010). Due to the greater subjectivity in the estimates and the need for training or continuous use of a diagrammatic scale, severity has been seldom used compared to that of incidence, a much simpler, faster, and more objective method. Therefore, it is essential to increase knowledge about the epidemiological processes of peanut smut that can be useful for the improving the management of the disease. The aims of the present work were to: (i) evaluate the intensity of smut in the main peanut-growing area of Argentina; (ii) summarize the distribution of the classes of disease severity in pods; and (iii) model the relationship between incidence and severity classes.

\section{Material and methods}

Sampling sites and survey description 
The survey was conducted in the main peanut cultivation area of Argentina (Córdoba province; Fig. 1).

94 Commercial peanut fields were selected from 11 departments in Cordoba from the 2014-2015 to 2019-2020

95

96

97

98

99
$\mathbf{A}_{2005}$

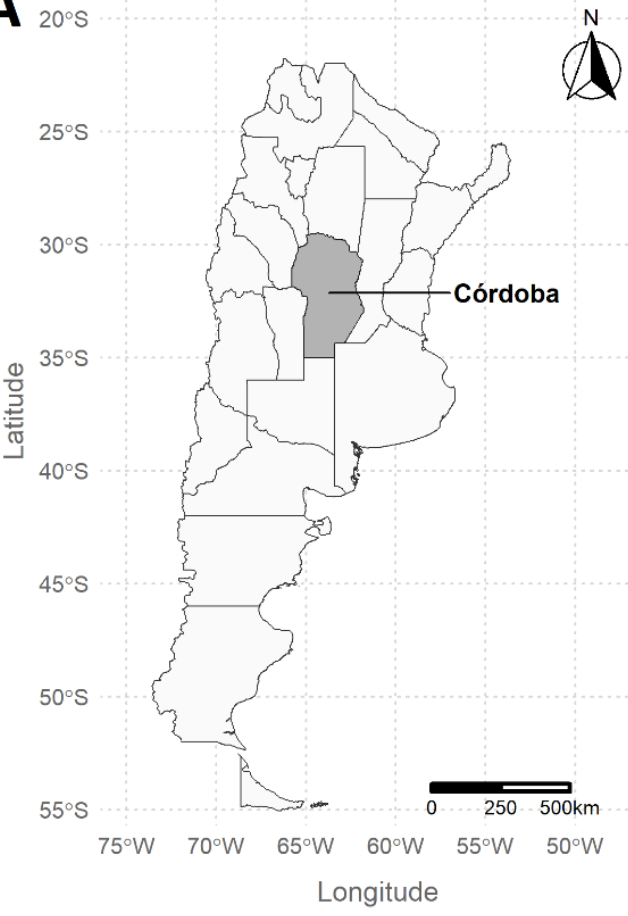

B

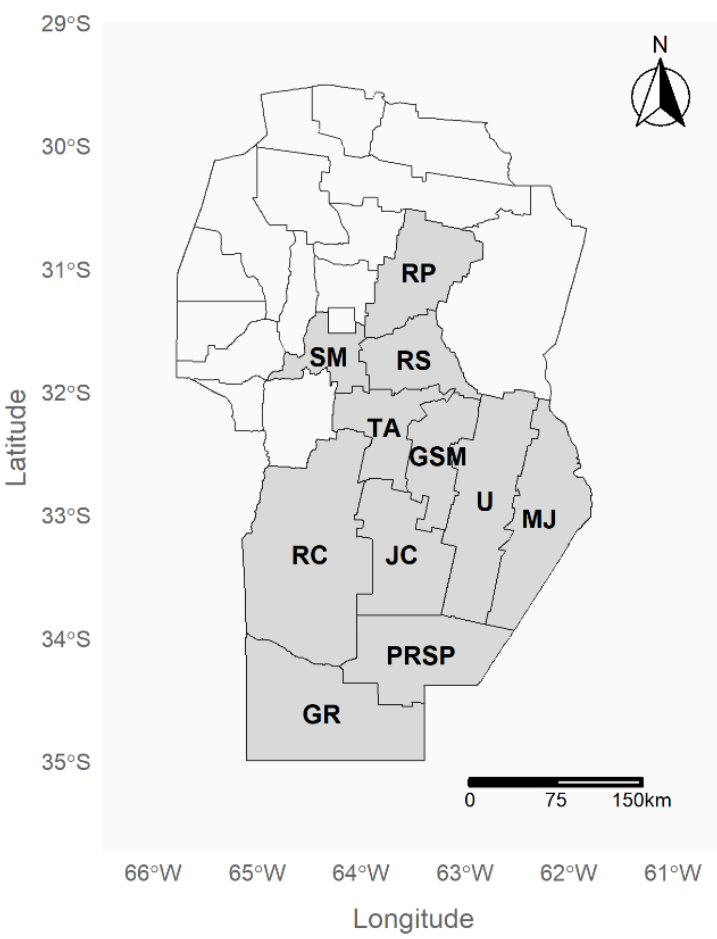
growing season (herein, 2015 to 2020, the harvest year). Fields were sampled at random to be representative to survey in the extension of the peanut-growing area. The closeness of the shelling plants was not considered, and the same field was non-sampled more than once. All surveyed fields were grown under natural conditions (without water systems), with grower's standard management practices. Field size ranged from 80 to 400 ha. No peanut smut management strategies were applied in any of the sampled fields. The dose and timing of fungicide spraying for foliar diseases (leaf spot) have no effect on smut control (Paredes et al., 2021).

Fig. 1. Location of the main peanut cultivation area in Argentina. A: The dark gray area corresponds to Córdoba province where the main peanut-growing region and peanut processing industries are located. B: Departments surveyed in Córdoba province, where: RP: Río Primero; SM; Santa María; RS: Río Segundo; TA: Tercero Arriba; GSM: General San Martín; U: Unión; MJ: Marcos Juárez; JC: Juárez Celman; RC: Río Cuarto; PRSP: Presidente Roque Sáenz Peña; GR: General Roca.

All sampled fields are infested with inoculum of peanut smut since natural smut infections were observed in each field. Smut intensity was determined in the mature crop at approximately 140 day after planting at stage R8 (Boote, 
110 1982; Rago et al., 2017). Disease assessments were performed by collecting all the plants in $1 \mathrm{~m}$ crop row at a

111 pre-harvest stage (sampling unit/station). Samples were collected in a transect in the central area of the field,

112 separated $50 \mathrm{~m}$ (at least) one each other. The number of samples ranged from 4 to 8 , depending on the regional

113 disease pressure according to Paredes et al. (2017). Four sample stations were enough for fields with high soil

114 inoculum pressure (>8\% incidence). Conversely, 8 samples were taken in fields with lower smut inoculum

115 pressure (<4\% incidence). All pods sampled at each station were evaluated.

116

117

Disease assessment and frequency of severity class

118 Peanut smut intensity was characterized by disease incidence (percentage of diseased pods out of the total of

119 sampled pods) and severity (proportion of visibly damaged pod tissue). Smut severity was indirectly assessed 120 using a five-class scale, in which the state of the individual pod damage was considered, wherein disease class ' 0 '

$121=$ both kernels healthy; class ' 1 ' = single kernel with a small sorus in a normal pod; class ' 2 ' = half of the kernel 122 affected in a deformed or normal pod; class ' 3 ' = one completely smutted kernel in a deformed pod; and class ' 4 '

123 = two completely smutted kernels in a deformed pod (Astiz Gasso et al., 2008; Rago et al., 2017). The disease 124 severity index (DSI) was calculated according to equation 1. Arbitrary metrics were also obtained: i) Low 125 Damaged Pods (LDP) included classes 1 and 2 as proportion of the total; and ii) Severely Damaged Pods (SDP) represented the proportion of classes 3 and 4 (Paredes et al., 2021). The distributions of disease severity classes were calculated as the severity class incidence (SCI) (2), expressed as a percentage of the total number of pods infected, and the relative frequency of disease severity classes ( $f$ DSC) (3):

$$
\mathrm{DSI}=(\Sigma(\mathrm{n} * \text { disease severity class }) /(\mathrm{N} \times 4)) \times 100
$$

$$
f \mathrm{DSC}_{\mathrm{x}}=\left(\mathrm{n}_{\mathrm{x}}\right) / \mathrm{N}_{\mathrm{i}}
$$
to each disease severity class (0-4), and $n_{x}$ is the number of pods corresponding to the $\mathrm{x}$-th disease severity class.

Data analysis 
136 The relationship between incidence (global and for each severity class) and DSI were analyzed by means of linear

137 regression models. We considered that fields within a same location and year were not independent, so we grouped

138 them into the same environment (i.d.). Then, we fitted mixed linear regression models to the data filtered by two

139 conditions: environments (departments) with at least four sampled fields and a range of smut incidence of at least

$1405 \%$. This restriction allowed us to estimate an id-level regression as a random effect and the overall line regression

141 as a fixed effect. With $n=20$ independent environments, the linear mixed model for environment $i$ may be written

142 as:

143

144

145

146

147

148

149

150

151

152

153

\section{Results}

155

156

157

158

159

160

\section{Peanut smut survey data}

From 2015 to 2020, 217 fields in Cordoba province were surveyed. Department surveys corresponded to the main peanut-growing region of Cordoba, Argentina (Fig. 2, Table 1). A total of 130 fields (60\% of surveyed fields) were collected in Rio Cuarto, General Roca and Presidente Roque Saenz Peña (most productive areas); 24, 22.6, and $13.4 \%$ of the fields were collected in those departments respectively. In addition, $40 \%$ of fields were surveyed in 2020, with a high volume of data in that year (87 fields). 

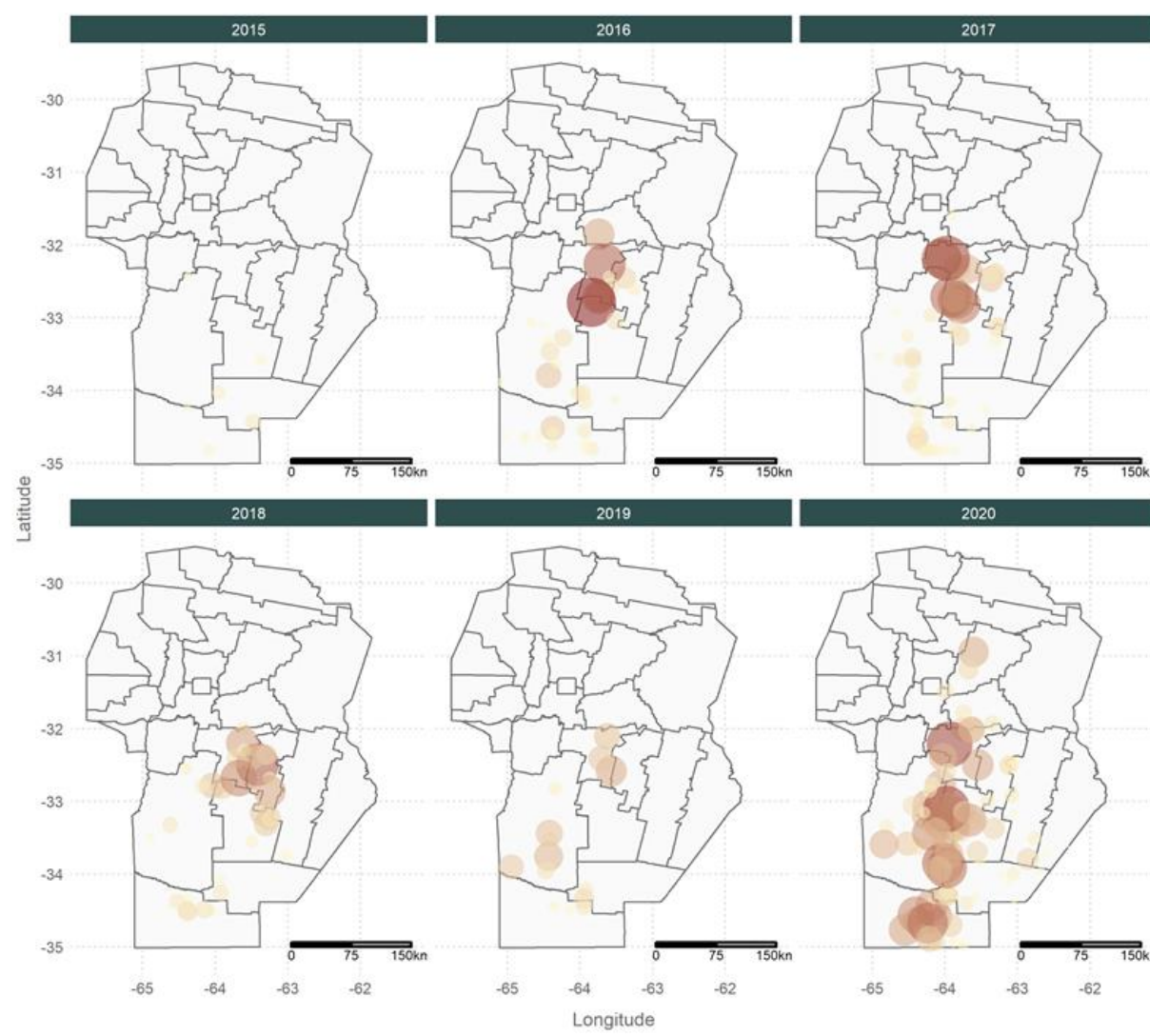
Incidence of
peanut smut

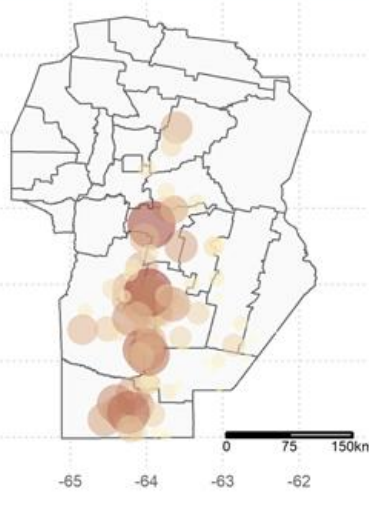

161 Fig. 2. Yearly maps (2015 to 2020) of peanut smut survey of 217 commercial peanut fields in 11 departments in

162 the main peanut-growing area in Córdoba province, Argentina.

Agronomic conditions of the crops varied among the years for edaphic factors or environmental variations. Accumulated rainfall recorded during the peanut cropping season (November to April) is presented in supplementary table (ST 1). In 2017, there was a severe drought (300 mm less than normal) during the growing season.

Table 2 summarizes data on disease incidence (DI) and DSI for the collected fields through years. Based on the samples in this study, from 2015 to 2020, no field with 0\% incidence was recorded in Córdoba province. The mean of the incidence increased from $1.66 \%$ in 2015 to $11.47 \%$ in 2020 . In general, smut severity index $(0.01$ to $>35 \%)$ and incidence (0.04 to >40\%) varied considerably within the same year, with exception of years 2015 and 2019 (Fig. 3). Out of the 217 fields sampled, 97 fields (44.7\%) showed a low intensity (DI < 4\%; DSI < 3), 89 fields $(41 \%)$ showed medium intensity (DI $>4$ to $<20 \%$; DSI $>2.3$ to $<15.4$ ), and 31 fields $(14.3 \%)$ showed a high intensity (DI $>20 \%$; DSI $>15$ ). 

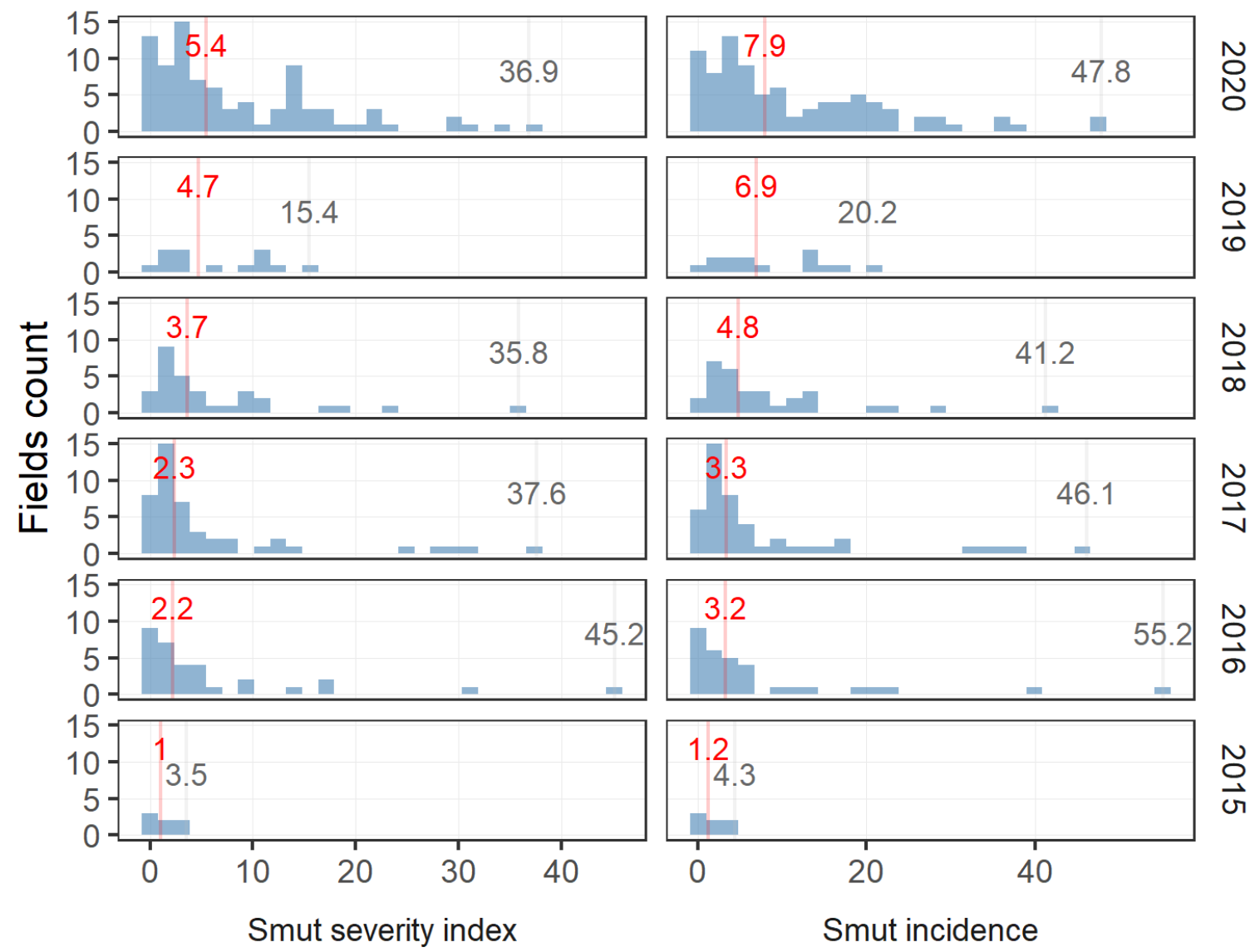

176 Fig. 3. Distribution of peanut smut severity index and incidence surveyed from 2015 to 2020 in Córdoba,

177 Argentina. The vertical red and grey lines represent the median and maximum values, respectively for each year.

178 With exception of years 2015 and 2019, both disease metrics presented a right skewed distribution, with more 179 than $50 \%$ of values lower than $10 \%$. This difference in the shape of the distribution between 2015 and 2019 with

180 the other years can be due to the low number of fields included in the survey ( $n=7$ and $n=14$, respectively; Table

181 1). Despite the lower number of assessed fields, both median values of DSI and incidence were similar to the other

182 years with higher totals of assessed fields. Median values of both smut intensity metrics consistently increased 183 from 2015 to 2020 with a higher increment of smut incidence ( +6.6 folds) than smut severity index ( +5.4 folds).

184 This differential relative change of both metrics can be explained by the decrease of smut severity class 4 in 185 contrast to an increase of smut severity class 1 along the period of study (Figure 4). Even with this variation of 186 disease severity class, frequency class 3 represented 41 to $47 \%$ of the total diseased pods, followed by class 4 , 187 with a frequency ranging from 28 to $44 \%$ over all surveyed years. In any of the years of survey, both class 3 and 1884 represented at least $75 \%$ of diseased pods (year 2019). In contrast, classes 1 and 2 showed the lowest frequency over the surveyed years (mean 13.36 and $11 \%$, respectively). 
A

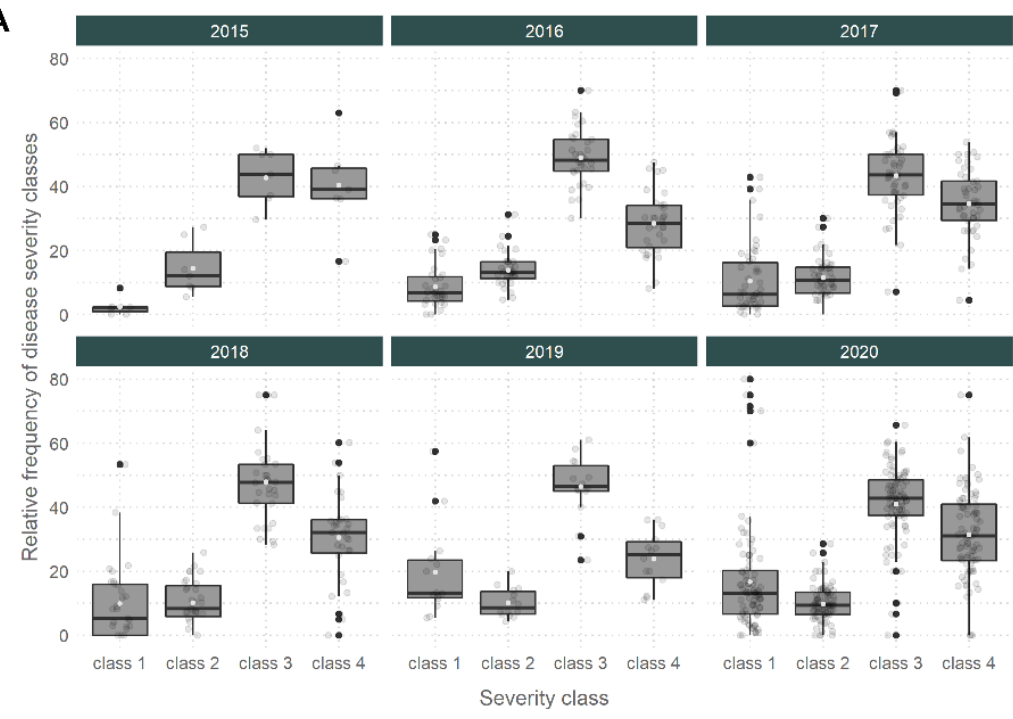

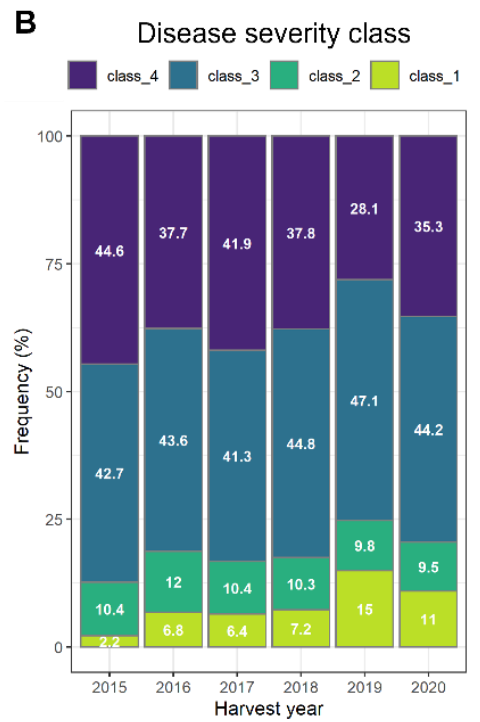

192 Fig. 4. A: Box plots showing the distribution of the relative frequency in disease severity classes for peanut smut

193 in fields surveyed from 2015 to 2020 . The solid line in the box represents the median, the white dots the mean,

194 the upper and lower limits of the boxes represent the 25th and 75th percentiles of the data, respectively, and the

195 black dots represent outliers. B: Stacked bar represents the mean of the relative frequency in disease severity 196 classes for peanut smut in fields surveyed from 2015 to 2020.

\section{Relationships analysis of smut intensity metrics}

199 The linear regression provided good enough to assess the relationship between smut intensity metrics (see model 200 diagnostic plots in Fig. S1). A wide range of smut data were used for the analysis, 74 fields grouped in 20 201 environments (field location department $\mathrm{x}$ year). From the decomposed analysis of each severity class incidence against field incidence, we observed that the best representation of disease incidence was by disease severity classes 3 and 4 as $\operatorname{SDP}(\beta 1=0.45$ and 0.35 , respectively; $\mathrm{P}<0.001)$. The lowest slopes were observed in severity classes from LDP, 0.061 and 0.095 for severity classes 1 and 2, respectively (RMSE $=0.736$ and 0.508 , respectively; $\mathrm{P}<0.001$, ). We also included in the analysis the incidence of SDP and obtained a $\beta 1=0.81$ $(\mathrm{P}<0.001, \mathrm{RMSE}=0,392)$. 

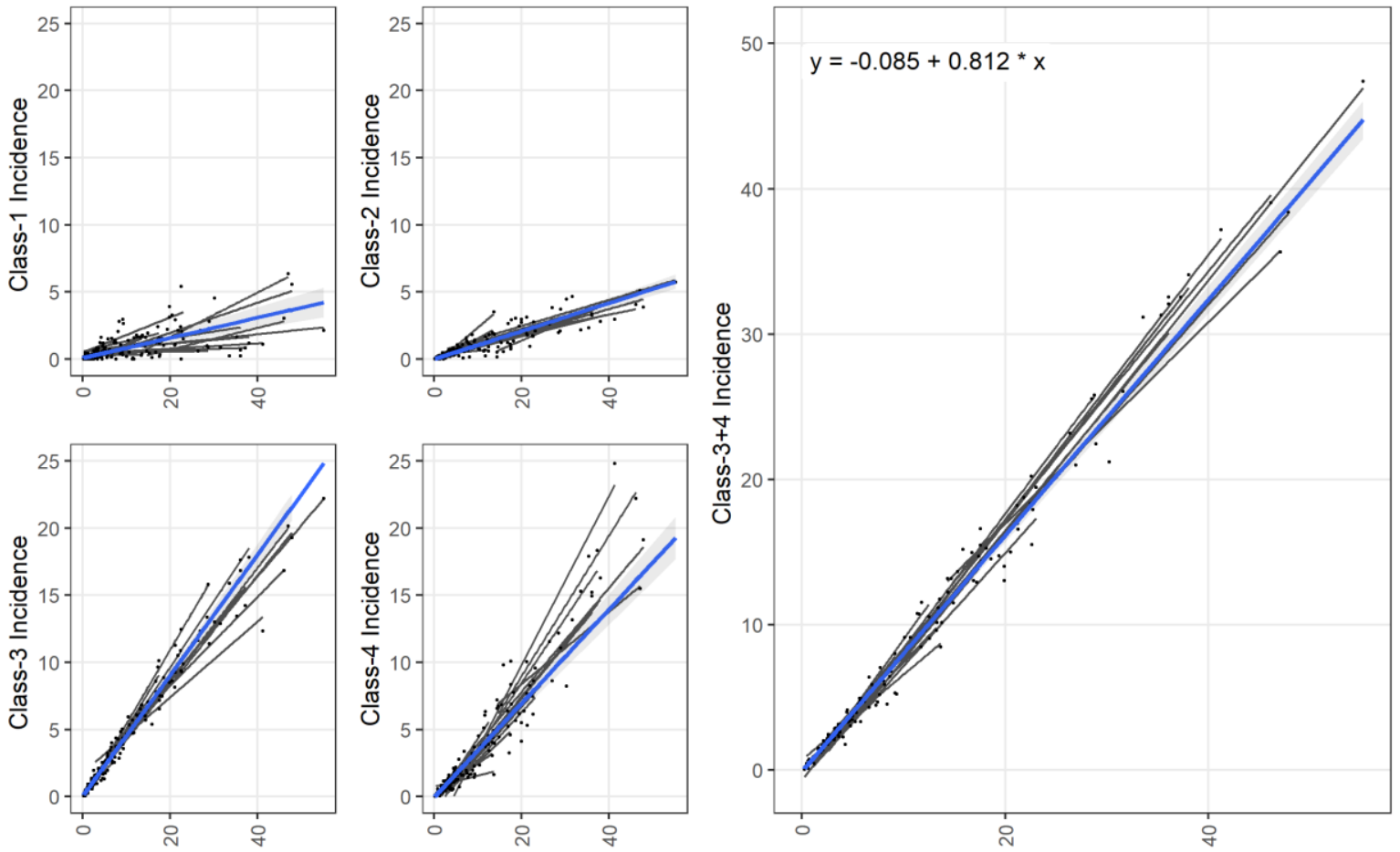

Disease incidence

208 Fig. 5. Regression lines for relationships between severity class incidence and incidence of peanut smut in fields surveyed from 2015 to 2020 in Córdoba, Argentina. Solid grey lines represent the study-specific relationships, the solid blue line represents the linear regression, and the grey shade area represents the $95 \%$ confidence interval.

212 Finally, we evaluated the relationship between disease incidence or SDP incidence and the DSI (Fig. 6). Smut incidence increased along the DSI values as a linear rate of 1.291. SPD incidence had the closest relationship with

214 SPD incidence $(\beta 1=1.054$, RMSE $=0,392)$. 

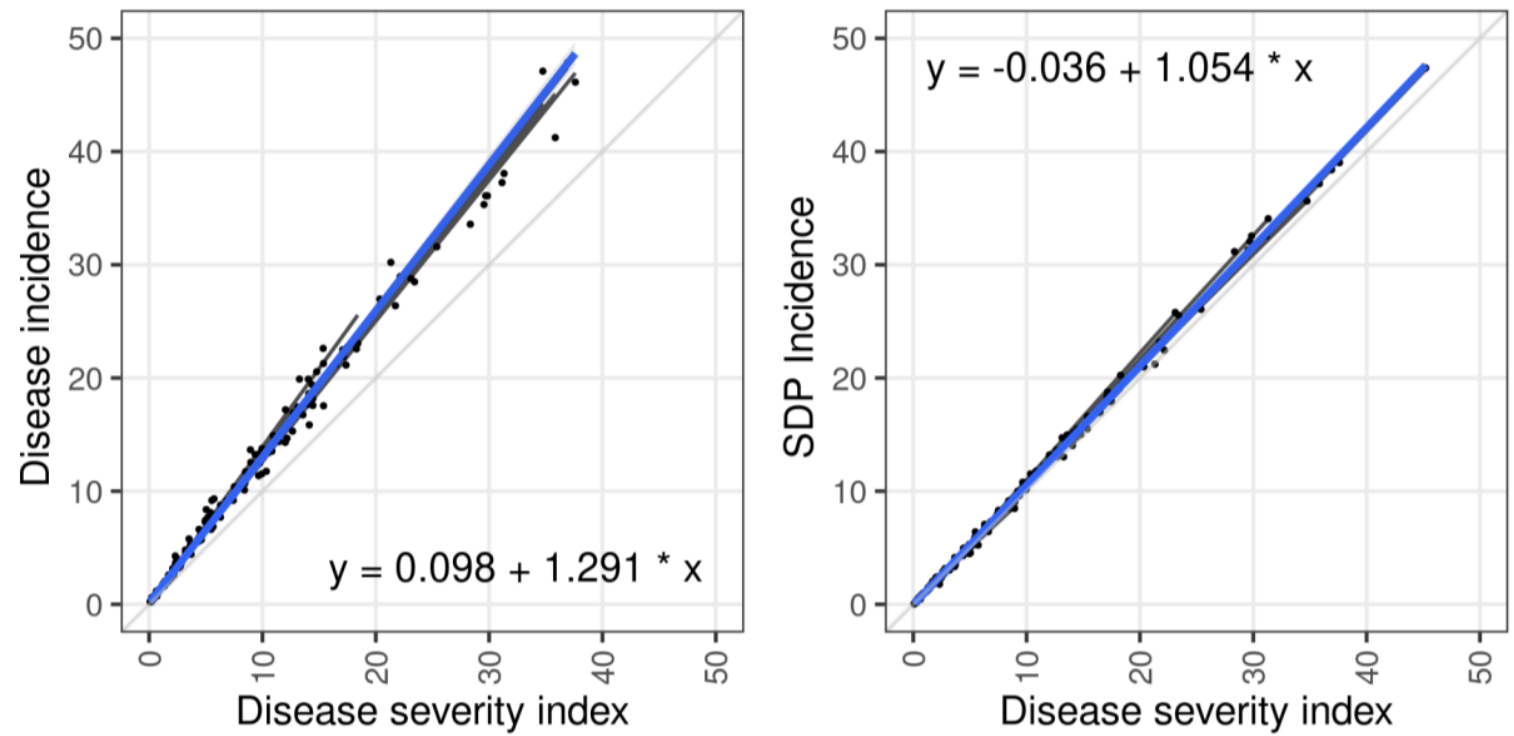

217 Fig. 6. Linear regression of the disease incidence (left) and severely damaged pods (SDP) (right) as a function of 218 disease severity index (DSI) of peanut smut in fields surveyed from 2015 to 2020 in Córdoba, Argentina. Solid grey lines represent the study-specific relationships, the solid blue line represents the linear regression, and the grey shade area represents the $95 \%$ confidence interval.

\section{Discussion}

Since the first report of peanut smut in commercial peanuts in 1995, the disease incidence and prevalence have gradually increased in the main peanut-growing region of Argentina (Asinari et al., 2019; Marinelli et al., 2010; Paredes et al., 2016; Rago et al., 2017). Based on the results of this study, in the last five years (2015-2020), peanut smut incidence and DSI increased from 1.67 to $11.47 \%$ and from 1.36 to 8.73 , respectively. Future increases are expected due to the lack of management practices adoption for controlling smut (Rago et al., 2017). In this study, the important areas for peanut cultivation in Córdoba were surveyed to assess the current impact of smut, representing the principal peanut production area in the country. Although more than $90 \%$ of total production is concentrated in Córdoba, peanuts are present in other provinces, such as Salta, San Luis, La Pampa, and Buenos Aires (Calzada \& Rozadilla, 2018). However, these areas are small, cultivation is inconsistent, and were considered negligible, not representative, or with minor importance on peanut cultivation in Argentina. To the best of our knowledge, this is the first analysis of the intensity of peanut smut in Córdoba province. disease, and the poor cultivar diversification in planting areas (Rago et al., 2017). Regarding genetic resistance, 
The area occupied by those varieties is not significant in relation to that currently cultivated with the most predominant variety. The challenge for breeding programs is to identify resistance genes in wild and cultivated germplasm to breed for high-yielding resistant cultivars and reduce teliospore production and delay the spread of smut (Bennett et al., 2021; Bressano et al., 2019; De Blas et al., 2019; Rago et al., 2017; Wann et al., 2020). In this survey, all samples were collected from commercial cultivars without tolerance to smut; our results indicate that the intensity and the analysis in this study is associated with susceptible host cultivars. However, genetic variation in pathogens may differentiate the variability in aggressiveness (Pariaud et al., 2009). The degree of genetic variability of $T$. frezii is not currently well documented, though phenotypic variability in its virulence is present.

247 Fungicide applications are not used to control smut due to their relative low efficacy. The target (soil and pegs) is

248 difficult to reach because of plant architecture at the pegging stage (Augusto et al., 2010; Cazón et al., 2018;

249 Paredes et al., 2021). Our observations were based on a limited number of fields and did not consider chemical

250 protection for other diseases. However, the most common fungicide programs to control peanut diseases in crops 251 (i.e., chlorothalonil to leaf spot) do not have smut control (Camiletti et al., 2021; Paredes et al., 2021; Rago et al., 252 2017).

253 In general, it is considered that the active movement of most soilborne pathogens in soils is very limited (Katan, 254 2017). Nevertheless, the spread of smut to other fields or regions is remarkable, indicating that they have effective 255 means for dispersal. The most effective way to spread soil-borne pathogens is by means of infected plant propagation material, e.g., seeds, tubers, transplants, and cuttings. However, other means of pathogen dispersal are via infested soil, or by being carried by agricultural tools and machines, water, and wind (Rekah et al., 1999). In Argentina, the increase in disease intensity and prevalence occurred in a relatively short period. Smut spores are commonly spread into dieses-free fields through infested seeds (Cazón, 2015; Rago et al., 2017). The determinant of reaching a $100 \%$ prevalence in the producing area was related to peanut companies that process commercial peanuts and peanut seeds in the same processing industries (Rago et al., 2017).

262 Polyetic characteristics of the disease (annual inoculum accumulation in the field in subsequent seasons) added to the survival capacity of spores in the soil, increased the disease incidence and prevalence. According to published studies, the spores can remain infective for more than 4 years in contaminated soils (Cazón et al., 2016). As we 
observed in this analysis, SDP represents the major infection in smut, and these severity classes were the most important in spore production. The intensity of smut symptoms (SDP) had an impact on the inoculum increase, as they were lost at harvest (Paredes et al., 2017). The major mechanism of inoculum spread is spore liberation from broken infected pods during the harvesting process since many spores can be dispersed by wind. Disease management programs must consider the easy spread of inoculum over short distances (Rago et al., 2017). In addition, most peanut processing factories are located in the same growing region (Agüero, 2017). Smutted pods may be carried to the industries and broken during the peanut processing. This leads to a high volume of spores that may be dispersed and accumulated in local fields around factories. This is confirmed by the highest incidence near these industries. In addition, regional incidence where industries were established leads to the highest values of incidence (i.e., Tercero Arriba and Juárez Celman).

The broken infested pods and the mobilization of soil in the harvest process might lead to a homogeneous distribution of spores in the soil. Levels of inoculum in the soil are widespread in Córdoba province, according to the incidence recorded in different surveys (Asinari et al., 2019; Cazón et al., 2018; Paredes, 2017). Fiers et al. (2012) indicated that for potato soilborne pathogens, there is not always a clear and linear relationship; the severity of the disease generally increases with an increasing level of inoculum. Sometimes, a minimum inoculum threshold is needed to initiate disease development. Although the incidence of smut is dependent on the soil inoculum in the soil (Paredes et al., 2019), our results showed that this variable does not affect the intensity of symptoms, as confirmed by the frequency of severity classes, which did not differ between levels of incidence.

In some pathosystems, severity is more difficult to assess, but it more accurately estimates intensity, especially in foliar disease (Marcuzzo \& Carvalho, 2017). The levels of the severity scale of smut are well-differentiated. However, more dispersion of data was observed in class 1, when symptoms were more difficult to discern. The same result was observed by Bennett et al. (2021), who observed that errors in measuring incidence were most likely to occur when severity was low (i.e., small solitary sorus was more likely to be missed). In many plant pathogens, there is a widespread tendency to overestimate disease severity at low severities $(<10 \%)$ (Bock et al., 2010).

A strong relationship between disease severity and incidence was observed in the current study. This finding confirms and is consistent with results by other researchers, with a strong and significant positive correlation between incidence and severity (Bennett et al., 2021; Kearney et al., 2021; Marraro Acuña et al., 2014). A strong correlation between incidence and severity allows for screening germplasms by only recording incidence (Seem, 

or symptom development, in which case incidence could continue to grow with less severe symptoms. A fit in the relationship could be necessary in that case. At present, Marraro Acuña et al. (2014) screened the intensity of smut from 10 genotypes and concluded that for peanut smut, incidence data were sufficient for resistance screening. In accordance, Bennett et al. (2021) suggested an alternative phenotyping approach that relies solely on rating pods for disease incidence. In addition, the slope of the line indicates the importance of each degree of severity in the

300 incidence of the disease. SDP represents more than $80 \%$ of infections, which demonstrates how aggressive peanut 301 smut can be. In addition, classes 3 and 4 represent the greatest impact on yield loss, the kernels have completely 302 smutted and had less quality in the peanut industry. The relationship between incidence and severity may also be compared with yield loss. Paredes (2017) showed a significant linear relationship between estimated yield losses and disease intensity.

305 Water limitation and drought stress conditions might influence the infection and severity of diseases (Kambiranda 306 et al., 2011). Increases in susceptibility or tolerance depends on the interaction and specific pathogen. In the case 307 of cyst nematode, the relationship between inoculum density and disease severity greatly depends on the 308 environmental factors that determine the level of soil suppressiveness (Fiers et al., 2012). Based on our experience,

309 peanut smut had an increased incidence when less precipitation was accumulated during the pegging phenological 310 stage (January to March), due to water stress periods (Paredes, unpublished). However, no differences were 311 observed in the frequency of severity classes of smut in this study.

312 Diseases caused by soilborne pathogens cause heavy losses to many crops (Katan, 2017). In many cases, they are 313 destructive and of high economic importance. Potato smut (Thecaphora solani) is one of the most destructive 314 fungal diseases affecting potato. In the northern part of Chile, this disease is established in many soils, causing 315 significant yield losses that often exceed 90\% (Andrade et al., 2004). Peanut smut had a remarkable increase in 316 disease incidence over the years (Asinari et al., 2019). In 2016, fields with high disease levels were commonly 317 located in the center of the province, near processing factories (Rago et al., 2017). However, in the last two years 318 a considerable increase in disease incidence was also observed in the south of the province. In other soil-borne 319 pathogens, Synchytrium endobioticum in potato is considered a highly destructive disease and may cause $100 \%$ 320 loss of potential tuber yield (Wale et al., 2011). Conversely, in peanut smut 100\% incidence has never been registered, even in experimental situations with high volume of spores in the soil (>15,000 teliospores/g of soil). 

$35 \%$ with $>50 \%$ incidence (Paredes, 2017).

In conclusion, data from the present study provided relevant information on the relationship between incidence and severity of smut. Peanut smut is highly aggressive, with an infected pod likely having a high disease severity, as confirmed by the close relationship between severity classes and incidence. The disease was not considered a serious threat for peanut cultivation at its re-emergence in 2006. Diverse factors have likely contributed to spread the disease within Córdoba province, making this disease the most serious phytopathological problem for peanut growers. The principal factor to increase spores in the soil is the production of spores due to the aggressiveness of smut result in a high spore production in the soil, with the subsequent spread among fields. This led to an increase of disease incidence in the main peanut-growing area. The results obtained in this work contribute to progress in the knowledge of the distribution of $T$. frezii in the main peanut-growing area of Argentina. In addition, we suggest assessing the disease by severely damaged pods (SDP). According to the data obtained, the incidence of SDP had the best representation of DSI, which is a faster method of quantifying peanut smut. SPD and incidence can be adopted for monitoring purposes, screening genotypes in breeding programs, or treatments comparisons in smut management experiments.

\section{Authors' contributions}

340 Juan Andres Paredes: Conceptualization, methodology, formal analysis and investigation, and writing

341 Juan Pablo Edwards Molina: Validation, formal analysis, visualization, and writing

342 Luis Ignacio Cazón: Writing methodology

343 Florencia Asinari: Data Curation

344 Joaquin Humberto Monguillot: Data collection

345 Sergio Alejandro Morichetti: Resources provision

346 Alejandro Mario Rago: Project administration

347 Adriana Mabel Torres: Supervision and writing

\section{Data availability statement}

The datasets generated during and/or analyzed during the current study are available from the corresponding author on reasonable request. 


\section{Ethics declarations}

Conflict of interest

On behalf of all authors, the corresponding author states that there is no conflict of interest. All authors gave

approval for submission of this manuscript. The authors declare that no conflicts of interest exist.

\section{Disclosures and declarations}

The manuscript has been prepared following principles of ethical and professional conduct. The research did not animals is applicable.

\section{Funding}

This work was supported by INTA [1090] and Fundación Maní Argentino.

\section{References}

Agüero, D. (2017). Mercado internacional y nacional del maní. In E. Fernandez \& O. Giayetto (Eds.), El cultivo de maní en Córdoba (Departamen, pp. 411-433). https://www.produccionvegetalunrc.org/docs/ECMC_2.pdf

Andrade O, Muñoz G, Galdames R, Durán P, Honorato R (2004) Characterization, in vitro culture, and molecular analysis of Thecaphora solani, the causal agent of potato smut. Phytopathology 94:875-882

Asinari, F., Paredes, J. A., Monguillot, J. H., Cazón, L. I., Edwards, J. P., \& Rago, A. M. (2019). Últimos años de registros del carbón del maní, ¿hacia donde vamos? In XXXIV Jornada Nacional del Maní.

Astiz Gasso, M., Leis, R., \& Marinelli, A. (2008). Evaluación de incidencia y severidad del carbón de maní (Thecaphora frezii) en infecciones artificiales, sobre cultivares comerciales de maní. In $1^{\circ}$ Congreso Argentino de Fitopatología (p. 161).

Augusto, J., Brenneman, T. B., Culbreath, A. K., \& Sumner, P. (2010). Night spraying peanut fungicides I. Extended fungicide residual and integrated disease management. Plant disease, 94(6), 676-682.

Bennett, R. S., Rodriguez, A. V., Baldessari, J. J., Chamberlin, K. D., Payton, M. E., \& Wang, N. (2021). A Note on the Association Between Thecaphora frezzii Infection and Peanut Pod Density. Peanut Science. https://doi.org/10.3146/ps20-27.1

Bock, C. H., Poole, G. H., Parker, P. E., \& Gottwald, T. R. (2010). Plant disease severity estimated visually, by digital photography and image analysis, and by hyperspectral imaging. Critical Reviews in Plant Sciences, 29(2), 59-107. https://doi.org/10.1080/07352681003617285

Boote, K. J. (1982). Growth Stages of Peanut ( Arachis hypogaea L.) 1 . Peanut Science, 9(1), 35-40. https://doi.org/10.3146/i0095-3679-9-1-11

Bressano, M., Massa, A. N., Arias, R. S., De Blas, F., Oddino, C., Faustinelli, P. C., Soave, S., Soave, J. H., Pérez, M. A., Sobolev, V. S., Lamb, M. C., Balzarini, M., Buteler, M. I., \& Seijo, J. G. (2019). Introgression of peanut smut resistance from landraces to elite peanut cultivars (Arachis hypogaea $\mathrm{L}$ ). PLoS ONE, 14(2). https://doi.org/10.1371/journal.pone.0211920

391 Calzada, J., \& Rozadilla, B. (2018). Argentina líder en exportaciones del complejo de Maní. 
https://www.bcr.com.ar/es/print/pdf/node/72852

Camiletti, B. X., Paredes, J. A., Monguillot, J. H., Grosso, N. R., \& Rago, A. M. (2021). Fungicide efficacy of nanocrystal-based formulations against peanut smut. Crop Protection, 143(December 2020), 105522. https://doi.org/10.1016/j.cropro.2020.105522

Cazón, L. I. (2015). DETECCIÓN MOLECULAR DE Thecaphora frezii Carranza \& Lindquist EN SEMILLAS DE MANÍ ( Arachis hypogaea L .) DETECCIÓN MOLECULAR DE Thecaphora frezii Carranza \& Lindquist EN SEMILLAS DE MANÍ ( Arachis hypogaea L .). Universidad Nacional de Códoba.

Cazón, L. I., Paredes, J. A., Bisonard, M., \& Rago, A. M. (2016). Capacidad de infección de Thecaphora frezii en el tiempo. In XXXI Jornada Nacional del Maní (p. 52).

Cazón, L. I., Paredes, J. A., \& Rago, A. M. (2018). The Biology of Thecaphora frezii Smut and Its Effects on Argentine Peanut Production. In Advances in Plant Pathology (p. 13). InTech. https://doi.org/10.5772/intechopen.75837

De Blas, F. J., Bressano, M., Teich, I., Balzarini, M. G., Arias, R. S., Manifesto, M. M., Costero, B. P., Oddino, C., Soave, S. J., Soave, J. A., Buteler, M. I., Massa, A. N., \& Seijo, J. G. (2019). Identification of smut resistance in wild arachis species and its introgression into peanut elite lines. Crop Science, 59(4), 16571665. https://doi.org/10.2135/cropsci2018.10.0656

Fiers, M., Edel-Hermann, V., Chatot, C., Le Hingrat, Y., Alabouvette, C., \& Steinberg, C. (2012). Potato soilborne diseases. A review. In Agronomy for Sustainable Development (Vol. 32, Issue 1). https://doi.org/10.1007/s13593-011-0035-z

Hammons, R. O., Herman, D., \& Stalker, H. T. (2016). Origin and Early History of the Peanut. Peanuts: Genetics, Processing, and Utilization, 1609, 1-26. https://doi.org/10.1016/B978-1-63067-038-2.00001-0

Kambiranda, D. M., Vasanthaiah, H. K., Katam, R., Ananga, A., Basha, S. M., \& Naik, K. (2011). Impact of Drought Stress on Peanut (Arachis hypogaea L.) Productivity and Food Safety. Plants and Environment. https://doi.org/10.5772/27917

Katan, J. (2017). Diseases caused by soilborne pathogens: Biology, management and challenges. Journal of Plant Pathology, 99(2), 305-315. https://doi.org/10.4454/jpp.v99i2.3862

Kearney, M. I., Kearney, M., Zuza, M., Ibañez, M., Peralta, V., Peiretti, G., Alcalde, M., Mojica, C., \& Rago, A. (2021). Response of peanut (Arachis hypogaea L.) genotypes to smut (Thecaphora frezii) in the peanut growing region of Argentina. Peanut Science. https://doi.org/10.3146/ps20-18.1

Marcuzzo, L. L., \& Carvalho, J. (2017). Relações lineares entre incidência e severidade foliar do míldio da cebola. Summa Phytopathologica, 43(4), 344-347. https://doi.org/10.1590/0100-5405/169894

Marinelli, A. D., March, G. J., Oddino, C. M., Garcia, J., Rago, A. M., \& Zuza, M. S. (2010). El carbón del maní de 1995 a 2010 de enfermedad emergente a enfermedad endémica y epidémica. In $25^{\circ}$ Jornada Nacional del Maní (pp. 28-30).

Marinelli, A., March, G. J., \& Oddino, C. (2008). Aspectos biológicos y epidemiológicos del carbón del maní (Arachis hypogaea L.) causado por Thecaphora frezii Carranza \& Lindquist. AgriScientia, 25(1), 1-5. https://doi.org/10.31047/1668.298x.v25.n1.2735

Marinelli, Adriana, March, G., \& Rago, A. M. (1995). El carbón del maní Thecaphora frezii sobre Arachis hypogaea L. In $7^{\circ}$ Congreso de Micología y $17^{\circ}$ Jornadas Argentinas de Micología (p. 134).

Marraro Acuña, F., Rodriguez, A. V., Edelstein, J. D., \& Baldessari, J. (2014). EVALUACIÓN DE LA INTENSIDAD DEL CARBÓN DEL MANÍ. In XXIX Jornada Nacional del Maní.

Oddino, C. M., Soave, J. A., Soave, S. J., Moresi, A., Bianco, C., Buteler, M. I., Faustinelli, P. del C., \& Torre, D. (2013). Avances genéticos en la tolerancia a carbón del maní causado por Thecaphora frezii. In XXVIII Jornada Nacional del Maní. (pp. 31-32).

Paredes, J. A., Cazón, L. I., Osella, A., Peralta, V., Alcalde, M., Kearney, M. I., Zuza, M. S., Rago, A. M., \& Oddino, C. (2016). Relevamiento regional del carbón del maní y estimación de pérdidas producidas por la enfermedad. In $31^{\circ}$ Jornada Nacional de Maní (pp. 53-54).

Paredes, J.A., Asinari, F., J.H., M., Edwards, J. P., Oddino, C., \& Rago, A. . (2019). Incidencia del carbón del maní en función del inóculo de Thecaphora frezii en el suelo. In XXXIV Jornada Nacional del Maní.

Paredes, J.A., Cazón, L. I., Bima, M., Kearney, M., Alcalde, M., Nicolino, J. M., \& Rago, A. . (2017). Protocolo 
de toma de muestras y evaluación para un correcto relevamiento del carbón del maní. In XXIII Jornada Nacional del Maní (pp. 59-61).

Paredes, J.A., Cazón, L. I., Oddino, C., Monguillot, J. H., Rago, A. M., \& Molina, J. P. E. (2021). Efficacy of fungicides against peanut smut in Argentina. Crop Protection, 140. https://doi.org/10.1016/j.cropro.2020.105403

Paredes, Juan Andrés. (2017). Importancia regional del carbón del maní (Thecaphora frezii) y efecto de ingredientes activos de fungicidas sobre la intensidad de la enfermedad. Universidad Nacional de Rio Cuarto.

Paredes, Juan Andrés, Cazón, L. I., \& Rago, A. M. (2017). Incremento de inóculo potencial según intensidad del carbón del maní. In XIX $X^{\circ}$ Congreso Latinoamericano de Fitopatología (p. 143).

Pariaud, B., Ravigné, V., Halkett, F., Goyeau, H., Carlier, J., \& Lannou, C. (2009). Aggressiveness and its role in the adaptation of plant pathogens. Plant Pathology, 58(3), 409-424. https://doi.org/10.1111/j.13653059.2009.02039.x

Rago, A. M., Cazón, L. I., Paredes, J. A., Molina, J. P. E., Conforto, E. C., Bisonard, E. M., \& Oddino, C. (2017). Peanut Smut: From an Emerging Disease to an Actual Threat to Argentine Peanut Production. Plant Disease, 101(3), 400-408. https://doi.org/10.1094/PDIS-09-16-1248-FE

Rekah, Y., Shtienberg, D., \& Katan, J. (1999). Spatial distribution and temporal development of fusarium crown and root rot of tomato and pathogen dissemination in field soil. Phytopathology, 89(9), 831-839. https://doi.org/10.1094/PHYTO.1999.89.9.831

Seem, R. C. (1984). Disease Incidence and Severity Relationships. Annual Review of Phytopathology, 22(1), 133-150. https://doi.org/10.1146/annurev.py.22.090184.001025

Team R Development Core. (2018). A Language and Environment for Statistical Computing. In $R$ Foundation for Statistical Computing (Vol. 2, p. https://www.R-project.org). http://www.r-project.org

Wale, S., Platt, H. W., \& Cattlin, N. (2011). Disease, Pests and Disorders of Potatoes, A Colour Handbook. Manson Publishing LTD, London., 64-65.

Wann, D. Q., Falco, A., Cavigliasso, M., \& Cassano, C. (2020). Phenotypic Variation of Peanut Smut ( 47(2), 46-53. https://doi.org/10.3146/ps20-4.1 
Table 1. Number of fields surveyed for peanut smut from 2015 to 2020 in different departments of Cordoba province, Argentina. Mean of smut incidence (\%) and disease severity index (DSI) according to department and year and the highest and lowest values for each field were summarized.

\begin{tabular}{|c|c|c|c|c|c|c|c|c|c|c|c|c|c|c|c|c|c|c|c|c|c|c|c|c|c|c|c|c|c|c|c|}
\hline \multirow{3}{*}{ Department } & \multicolumn{5}{|c|}{2015} & \multicolumn{5}{|c|}{2016} & \multicolumn{5}{|c|}{2017} & \multicolumn{5}{|c|}{2018} & \multicolumn{5}{|c|}{2019} & \multicolumn{6}{|c|}{2020} \\
\hline & \multicolumn{3}{|c|}{ Incidence } & \multicolumn{2}{|c|}{ DSI } & \multicolumn{3}{|c|}{ Incidence } & \multicolumn{2}{|c|}{ DSI } & \multicolumn{3}{|c|}{ Incidence } & \multicolumn{2}{|c|}{$D S I$} & \multicolumn{3}{|c|}{ Incidence } & \multicolumn{2}{|c|}{$D S I$} & \multicolumn{3}{|c|}{ Incidence } & \multicolumn{2}{|c|}{$D S I$} & \multicolumn{3}{|c|}{ Incidence } & \multicolumn{2}{|c|}{ DSI } & \multirow[b]{2}{*}{$\begin{array}{c}\text { Total } \\
\text { of } \\
\text { fields }\end{array}$} \\
\hline & $\mathrm{n}$ & mean & $\begin{array}{l}\min \\
\max \end{array}$ & mean & $\begin{array}{l}\min \\
\max \end{array}$ & $\mathrm{n}$ & mean & $\begin{array}{l}\min \\
\max \end{array}$ & mean & $\begin{array}{l}\min \\
\max \end{array}$ & $\mathrm{n}$ & mean & $\begin{array}{l}\min \\
\max \end{array}$ & mean & $\begin{array}{l}\min \\
\max \end{array}$ & $\mathrm{n}$ & mean & $\begin{array}{l}\min \\
\max \end{array}$ & mean & $\begin{array}{l}\min \\
\max \end{array}$ & $\mathrm{n}$ & mean & $\begin{array}{l}\min \\
\max \end{array}$ & mean & $\begin{array}{l}\min \\
\max \end{array}$ & $\mathrm{n}$ & mean & $\begin{array}{l}\min \\
\max \end{array}$ & mean & $\begin{array}{l}\min \\
\max \end{array}$ & \\
\hline \multirow{2}{*}{ General Roca } & 1 & 156 & 1.56 & 138 & 1.38 & 11 & 254 & 0.38 & 187 & 0.27 & 14 & 282 & 0.63 & 218 & 0.45 & 6 & 406 & 1.22 & 282 & 0.87 & 2 & 13 & 0.91 & 074 & 0.59 & 18 & 1241 & 1.17 & 1032 & 0.64 & 52 \\
\hline & 1 & 1.00 & 1.56 & 1.00 & 1.38 & 11 & 2.04 & 12.16 & 1.01 & 9.24 & 14 & 2.02 & 9.19 & 2.10 & 7.43 & 0 & 4.00 & 7.29 & 2.02 & 4.94 & 2 & 1.13 & 1.35 & 0.14 & 0.88 & 10 & 15.41 & 36.09 & 10.02 & 29.7 & 52 \\
\hline General San & & & & & & 2 & 582 & 2.83 & 443 & 2.07 & 4 & 714 & 2.09 & 560 & 1.54 & 5 & 1738 & 2.96 & 1427 & 2.22 & & & & & & 5 & 284 & 1.88 & 270 & 1.44 & 16 \\
\hline Martín & & & & & & 2 & 3.02 & 8.81 & $4.7 \mathrm{~J}$ & 6.79 & 7 & 1.17 & 13.41 & 5.00 & 10.53 & $J$ & 17.50 & 41.23 & & 35.83 & & & & & & $J$ & 5.04 & 6.22 & 2.10 & 4.87 & 10 \\
\hline $\operatorname{lman}$ & 1 & 123 & 1.23 & 101 & 1.01 & 4 & 2558 & 5.76 & 2032 & 4.49 & 0 & 1602 & 2 & 1363 & 1.64 & 6 & 885 & 2.12 & 726 & 1.72 & & & & & & 13 & 1076 & 1.07 & 760 & 0.77 & 33 \\
\hline 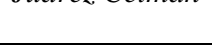 & & & 1.23 & & 1.01 & & 20.00 & 55.21 & & 45.21 & & & 37.26 & & 31.14 & 0 & 0.00 & 12.48 & 1.20 & 10.34 & & & & & & 10 & 10.70 & 23.06 & 1.00 & 18.41 & J \\
\hline Marces Jurez & & & & & & & & & & & & & & & & & & & & & & & & & & 2 & 016 & 0.04 & 005 & 0.01 & \\
\hline Marcos Juarez & & & & & & & & & & & & & & & & & & & & & & & & & & 2 & 0.10 & 0.29 & 0.05 & 0.09 & 2 \\
\hline Pte. Rque Saenz & 2 & 36 & 2.86 & 205 & 2.37 & 4 & 321 & 0.85 & 230 & 0.65 & 4 & 107 & 0.64 & 074 & 0.53 & 2 & 31 & 1.43 & 222 & 1.02 & 2 & 5.61 & 3.93 & $352+>>$ & 1.86 & 14 & 106 & 0.24 & 897 & 0.09 & 20 \\
\hline Peña & 2 & 3.0 & 4.34 & 2.0J & 3.53 & 4 & $J .21$ & 4.63 & 2.07 & 3.5 & 4 & 1.07 & 1.61 & 0.17 & 1.09 & 2 & 3.1 & 4.78 & 2.22 & 3.41 & J & J.01 & 8.05 & (5.J & 5.97 & 14 & 10.00 & 38.06 & 0.21 & 31.32 & 29 \\
\hline 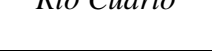 & $J$ & 0.04 & 0.7 & 0.42 & 0.57 & 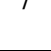 & 4.19 & 13.23 & 5.00 & 9.37 & 10 & $2.0 \mathrm{~J}$ & 5.83 & 2.01 & 4.41 & $\mathrm{~J}$ & 4.9 & 13.65 & 5.24 & 8.94 & 0 & 9.02 & 17.41 & 0.92 & 13.13 & 10 & 14.91 & 47.84 & & 36.91 & 4 \\
\hline & & & & & & & & & & & & & & & & & & & & & & & & & & & & 7.89 & & 5.38 & \\
\hline Rio Primero & & & & & & & & & & & & & & & & & & & & & & & & & & 2 & 13.74 & 19.59 & 9.75 & 14.13 & 2 \\
\hline$d \rho$ & & & & & & & & 20.73 & & 16.93 & & 120 & 1.39 & 070 & 0.79 & & & & & & & & & & & & 64 & 4.36 & & 3.29 & 5 \\
\hline Rio Segundo & & & & & & 1 & 20.13 & 20.73 & 16.93 & 16.93 & 1 & 1.39 & 1.39 & 0.19 & & & & & & & & & & & & 3 & 6.4 & 9.96 & 4.88 & 7.69 & $\mathbf{5}$ \\
\hline & & & & & & & & & & & & & & & & & & & & & & & & & & 1 & 503 & 5.03 & 310 & 3.1 & 1 \\
\hline Santa Marla & & & & & & & & & & & & & & & & & & & & & & & & & & 1 & 5.03 & 5.03 & 3.10 & 3.1 & 1 \\
\hline Torcor & & & & & & 2 & $1564+2+3$ & 1.92 & & 1.49 & 1 & 5 & 14.67 & & 12.17 & 5 & 5 & 2.6 & & 2.01 & 2 & 1504 & 13.29 & & 10.39 & 5 & 2 & 14.31 & 2 & 11.48 & \\
\hline Iercero Arrtoa & & & & & & 3 & 15.04 & 39.33 & 12.40 & 31.84 & 4 & $20.4 J$ & 46.13 & 25.53 & 37.61 & $J$ & 12.90 & 28.77 & 10.10 & 23.11 & 3 & 15.04 & 20.21 & & 15.45 & 3 & 22.15 & 47.1 & 1.05 & 34.74 & 20 \\
\hline Lnitón & & & & & & & & & & & & & & & & $?$ & 065 & 0.12 & $022+2$ & 0.09 & & & & & & 6 & 221 & 0.23 & 171 & 0.16 & $\mathbf{9}$ \\
\hline Union & & & & & & & & & & & & & & & & 2 & 0.05 & 1.19 & 0.33 & 0.57 & & & & & & 0 & 2.31 & 9.15 & 1.14 & 6.83 & $\boldsymbol{\delta}$ \\
\hline
\end{tabular}


474 Table 2. Descriptive statistics for peanut smut disease incidence and disease severity index (DSI) in fields 475 surveyed from 2015 to 2020.

\begin{tabular}{|c|c|c|c|c|c|c|c|c|c|c|c|}
\hline \multirow{2}{*}{ Year } & \multirow{2}{*}{$\begin{array}{c}\text { n of } \\
\text { fields }\end{array}$} & \multicolumn{5}{|c|}{ Incidence $(\%)$} & \multicolumn{5}{|c|}{ DSI } \\
\hline & & Mean & SD & $\mathrm{CV}$ & $\min$ & $\max$ & Mean & SD & $\mathrm{CV}$ & $\min$ & $\max$ \\
\hline 2015 & 7 & 1.66 & 1.45 & 87.11 & 0.43 & 4.34 & 1.36 & 1.19 & 87.55 & 0.3 & 3.53 \\
\hline 2016 & 32 & 7.87 & 12.12 & 154.06 & 0.38 & 55.21 & 6.12 & 9.84 & 160.73 & 0.27 & 45.21 \\
\hline 2017 & 46 & 8 & 11.15 & 139.3 & 0.6 & 46.13 & 6.38 & 9.23 & 144.64 & 0.4 & 37.61 \\
\hline 2018 & 31 & 8.42 & 9.23 & 109.55 & 0.12 & 41.23 & 6.63 & 7.79 & 117.57 & 0.09 & 35.83 \\
\hline 2019 & 14 & 8.88 & 6.36 & 71.66 & 0.91 & 20.21 & 6.45 & 5.03 & 77.99 & 0.59 & 15.45 \\
\hline 2020 & 87 & 11.47 & 11.06 & 96.39 & 0.04 & 47.84 & 8.73 & 8.7 & 99.56 & 0.01 & 36.91 \\
\hline
\end{tabular}

476

477

478 


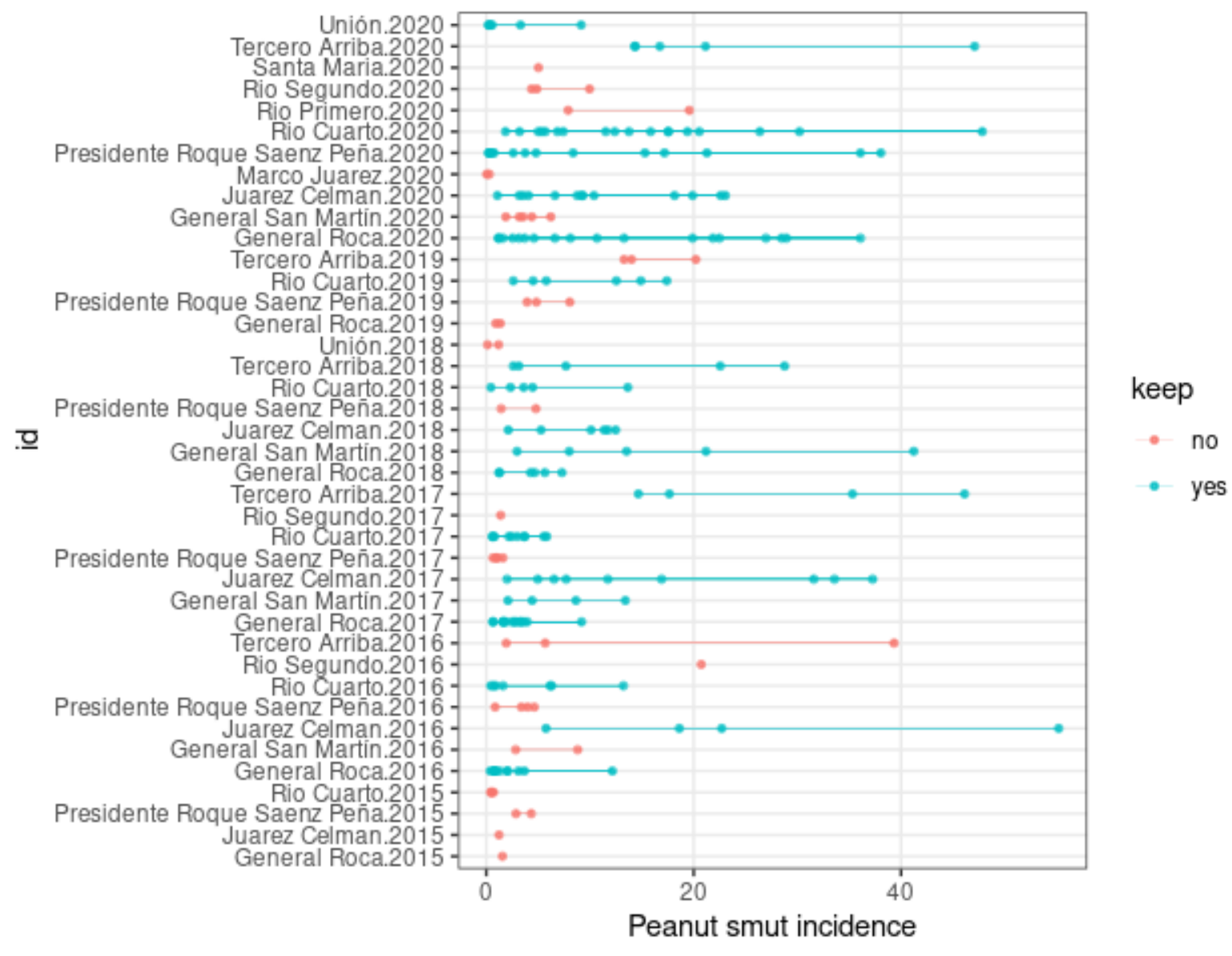

484 Fig. S1. Data filtering criterion for the random coefficient regression analysis: environments composed by the interaction of the field location and year of sampling with at least 4 fields and a range of smut incidence of 5\% were kept for modeling purposes. 
492 ST 1. Accumulated precipitation registered (mm) during the peanut cropping season (November to April) in the growing season surveyed (2014-15 to 2019-20)

\begin{tabular}{|c|c|c|c|c|c|c|c|c|c|c|c|c|c|c|c|c|c|c|c|c|c|}
\hline \multirow[b]{2}{*}{ Department } & \multicolumn{7}{|c|}{ 2014-15 } & \multicolumn{6}{|c|}{$2015-16$} & \multicolumn{8}{|c|}{ 2016-17 } \\
\hline & Nov & Dec & Jan & Feb & Mar & Apr & Acumulated & Nov & Dec & Jan & Feb & Mar & Apr & Acumulated & Nov & Dec & Jan & Feb & Mar & Apr & Acumulated \\
\hline General Roca & 61 & 102 & 124 & 139 & 56 & 80 & 561 & 179 & 89 & 259 & 97 & 32 & 113 & 769 & 44 & 106 & 98 & 76 & 194 & 120 & 638 \\
\hline Gral. San Martín & 80 & 94 & 148 & 275 & 191 & 48 & 836 & 172 & 112 & 132 & 264 & 51 & 134 & 865 & 22 & 114 & 103 & 125 & 81 & 79 & 523 \\
\hline Juárez Celman & 93 & 100 & 76 & 243 & 119 & 90 & 720 & 158 & 98 & 155 & 198 & 67 & 101 & 777 & 20 & 64 & 114 & 116 & 73 & 86 & 473 \\
\hline Marcos Juárez & 112 & 132 & 116 & 145 & 169 & 101 & 775 & 175 & 105 & 152 & 187 & 67 & 111 & 797 & 36 & 94 & 128 & 81 & 111 & 131 & 580 \\
\hline Pte. Roq. Sáenz Peña & 79 & 132 & 144 & 147 & 127 & 98 & 726 & 115 & 137 & 279 & 115 & 68 & 74 & 787 & 49 & 146 & 153 & 102 & 152 & 136 & 738 \\
\hline Río Cuarto & 110 & 98 & 82 & 251 & 127 & 52 & 719 & 180 & 112 & 168 & 143 & 91 & 96 & 790 & 31 & 75 & 118 & 79 & 101 & 85 & 489 \\
\hline Río Primero & 79 & 98 & 139 & 333 & 125 & 46 & 819 & 78 & 75 & 66 & 177 & 84 & 123 & 603 & 74 & 88 & 111 & 163 & 51 & 41 & 527 \\
\hline Río Segundo & 101 & 97 & 160 & 278 & 134 & 37 & 807 & 121 & 85 & 99 & 239 & 79 & 174 & 797 & 50 & 133 & 119 & 136 & 63 & 80 & 582 \\
\hline Tercero Arriba & 75 & 101 & 155 & 185 & 163 & 47 & 726 & 123 & 82 & 125 & 275 & 65 & 138 & 808 & 37 & 91 & 89 & 133 & 81 & 50 & 481 \\
\hline Unión & 99 & 99 & 146 & 246 & 185 & 64 & 839 & 138 & 111 & 138 & 201 & 63 & 113 & 764 & 22 & 111 & 105 & 125 & 82 & 102 & 547 \\
\hline Total & & & & & & & 753 & & & & & & & 776 & & & & & & & 558 \\
\hline \multicolumn{8}{|c|}{$2017-18$} & \multicolumn{6}{|c|}{ 2018-19 } & \multicolumn{8}{|c|}{ 2019-20 } \\
\hline Department & Nov & Dec & Jan & $\mathrm{Feb}$ & Mar & Apr & Acumulated & Nov & Dec & Jan & Feb & Mar & Apr & Acumulated & Nov & Dec & Jan & Feb & Mar & Apr & Acumulated \\
\hline General Roca & 70 & 75 & 60 & 9 & 10 & 44 & 268 & 128 & 58 & 128 & 48 & 53 & 53 & 469 & 86 & 92 & 130 & 38 & 156 & 45 & 547 \\
\hline Gral. San Martín & 43 & 152 & 36 & 6 & 18 & 118 & 373 & 249 & 148 & 119 & 23 & 160 & 93 & 791 & 54 & 111 & 125 & 120 & 98 & 18 & 526 \\
\hline Juárez Celman & 73 & 141 & 51 & 9 & 16 & 114 & 404 & 185 & 112 & 169 & 29 & 137 & 77 & 709 & 75 & 138 & 107 & 149 & 135 & 15 & 618 \\
\hline Marcos Juárez & 14 & 160 & 64 & 7 & 14 & 159 & 418 & 177 & 142 & 201 & 31 & 116 & 116 & 783 & 76 & 160 & 124 & 168 & 129 & 53 & 711 \\
\hline Pte. Roq. Sáenz Peña & 93 & 90 & 104 & 11 & 38 & 72 & 408 & 62 & 94 & 159 & 24 & 78 & 50 & 467 & 63 & 149 & 154 & 121 & 205 & 48 & 739 \\
\hline Río Cuarto & 27 & 109 & 95 & 32 & 15 & 61 & 339 & 153 & 72 & 163 & 30 & 173 & 55 & 646 & 99 & 79 & 95 & 125 & 142 & 35 & 574 \\
\hline Río Primero & 66 & 101 & 80 & 30 & 5 & 36 & 318 & 95 & 66 & 230 & 50 & 128 & 145 & 714 & 130 & 111 & 63 & 172 & 69 & 28 & 573 \\
\hline Río Segundo & 22 & 123 & 91 & 43 & 6 & 57 & 342 & 144 & 76 & 199 & 65 & 126 & 126 & 736 & 87 & 149 & 37 & 150 & 97 & 21 & 540 \\
\hline Tercero Arriba & 63 & 137 & 91 & 44 & 15 & 82 & 432 & 205 & 78 & 212 & 50 & 245 & 130 & 920 & 43 & 93 & 62 & 125 & 115 & 29 & 467 \\
\hline Unión & 65 & 166 & 60 & 5 & 11 & 135 & 442 & 216 & 138 & 183 & 45 & 125 & 83 & 790 & 68 & 136 & 120 & 148 & 120 & 32 & 625 \\
\hline
\end{tabular}

